\title{
Inter-site variation in allometry and wood density of Goupia glabra Aubl. in Amazonia
}

\author{
N. C. Siliprandi ${ }^{a}$, E. M. Nogueira ${ }^{a}$, J. J. Toledo ${ }^{b}$, P. M. Fearnside and H. E. M. Nascimento $^{a *}$ \\ ${ }^{a}$ Curso de Pós-graduação em Ciências de Florestas Tropicais, Instituto Nacional de Pesquisas da Amazonia - INPA, \\ Avenida André Araújo, 2936, Petrópolis, CEP 69067-375, Manaus, AM, Brazil \\ ${ }^{b}$ Curso de Pós-graduação em Biodiversidade Tropical, Universidade Federal do Amapá - UNIFAP, \\ Rodovia Juscelino Kubitschek, Km 02, Jardim Marco Zero, CEP 68902-280, Macapá, AP, Brazil \\ *e-mail: hnasci@gmail.com
}

Received: October 28, 2014 - Accepted: December 18, 2014 - Distributed: February 29, 2016

(With 4 figures)

\begin{abstract}
The present study aims to compare the allometry and wood density of Goupia glabra Aubl. (Goupiaceae) in two different terra-firme sites in Amazonian forest. A total of 65 trees $\geq 10 \mathrm{~cm} \mathrm{DBH}$ was sampled in both sites, with 39 trees in Nova Olinda do Norte (NOlinda, near the Amazon River) and 29 trees in Apuí (near the southern edge of the Amazon forest). Except for the relationship between DBH (diameter at breast height) and $\mathrm{H}_{\mathrm{t}}$ (total height), allometric relationships for G.glabra differed significantly between sites. Apuí had lower intercept and greater slope for $\log _{10}(\mathrm{DBH})$ versus $\log _{10}$ $\left(\mathrm{H}_{\mathrm{s}}\right.$ - stem height), and, conversely, greater intercept and lower slope for $\log _{10}(\mathrm{DBH})$ versus $\log _{10}\left(\mathrm{C}_{\mathrm{h}}-\right.$ crown height). The slope differed significantly between the sites for DBH versus $\mathrm{C}_{\mathrm{d}}$ (crown diameter), with greater slope found for NOlinda. Mean basic wood density in Apuí was 8.8\% lower than in NOlinda. Our findings highlight the variation in adaptive strategy of $G$. glabra due to environmental differences between sites. This is probably because of different canopy-understory light gradients, which result in differentiation of resource allocation between vertical and horizontal growth, which, in turn, affects mechanical support related to wood density. We also hypothesize that differences in soil fertility and disturbance regimes between sites may act concomitantly with light.
\end{abstract}

Keywords: allometric relationships, functional traits, phenotypic plasticity, tropical tree species.

\section{Variação entre-sítios na alometria e densidade da madeira de Goupia glabra Aubl. na Amazônia}

\section{Resumo}

O presente estudo tem como objetivo comparar a alometria e a densidade da madeira de Goupia glabra em dois diferentes sítios de floresta de terra firme na Amazonia. Um total de 65 árvores com DAP $\geq 10 \mathrm{~cm}$ foi amostrado em ambos os sítios, sendo 39 árvores em Nova Olinda do Norte (NOlinda, próximo ao rio Amazonas) e 29 em Apuí (próximo à borda sul da Amazônia). Exceto para a relação entre o DBH (diâmetro a altura do peito) e a $\mathrm{H}_{\mathrm{t}}$ (altura total), as relações alométricas para G. glabra diferiu significativamente entre os sítios. Apuí apresentou menor intercepto e maior inclinação para a relação $\log _{10}(\mathrm{DBH})$ versus $\log _{10}\left(\mathrm{H}_{\mathrm{s}}-\right.$ altura do fuste $)$ e, ao contrário, maior intercepto e menor inclinação para $\log _{10}$ $(\mathrm{DBH})$ versus $\log _{10}\left(\mathrm{C}_{\mathrm{h}}\right.$ - altura da copa). A inclinação diferiu significativamente entre os sítios para $\mathrm{DBH}$ versus $\mathrm{C}_{\mathrm{d}}$ (diâmetro da copa), com maior inclinação encontrada para NOlinda. A densidade básica média da madeira in Apuí foi $8.8 \%$ menor do que em NOlinda. Os resultados deste estudo destacam a variação na estratégia adaptativa de G. glabra devido às diferenças ambientais entre os sítios. Isto é provavelmente consequência dos diferentes gradientes de luz o que resulta na diferenciação na alocação de recursos entre o crescimento vertical e horizontal o que, por sua vez, afeta o suporte mecânico relacionado à densidade da madeira. Nós também levantamos a hipótese de que as diferenças em termos de fertilidade e regimes de distúrbios entre os sítios podem agir concomitantemente com o regime de luz.

Palavras-chave: relações alométricas, características funcionais, plasticidade fenotípica, espécies arbóreas tropicais.

\section{Introduction}

In tropical forests light is one of the most limiting resources for tree growth. The ability of a tree to assimilate light energy depends on the relationships between the size of

the tree (height and diameter) and crown size (both vertical and horizontal dimensions), i.e., the tree allometry - the spatial distribution of its components along the vertical 
axis (King, 1996; Poorter et al., 2006). Since there is a gradient of light availability ranging from a low light level in the understory to a high one in the forest canopy, allometric differences are expected among tropical tree species because of their differences in light requirements (Chazdon and Fetcher, 1984). In this sense, low-statured and shade-tolerant understory tree species, which are adapted to low light environments for establishment and growth, tend to have proportionally wider and shallower crowns in order to (i) increase their ability to assimilate light along the horizontal light gradient and (ii) avoid self-shedding. Conversely, shade-intolerant pioneer species, which only grow in gaps and/or are highly light demanding, invest proportionally more in height growth, increasing crown depth while reducing crown horizontal expansion (King, 1996; Thomas, 1996; Sterck et al., 2001; Alves and Santos, 2002).

Interspecific variation in allometry may be related to wood density because density correlates with mechanical support (King, 1981; Niklas, 1993; Putz et al., 1983). Light-demanding pioneer species in gaps need to invest more in growth to reach the canopy rapidly and to better compete with other tree species. In contrast, shade-tolerant species allocate more energy to survival through greater investment in mechanical support. Therefore, there is a tradeoff in biomass allocation (and, by inference, wood density) due to the different costs of support between these two extremes. Pioneer trees require less investment in wood tissue to sustain their crown, giving them more rapid growth and lower support costs, whereas shade-tolerant species invest more in building tissues (and thus have higher wood density), decreasing their susceptibility to physical damage, which ultimately results in a greater survival advantage (Putz et al., 1983; Thomas, 1996; King et al., 2006; Poorter et al., 2006).

Although the patterns of differentiation in architecture and wood density among functional groups of trees are widely recognized, studies assessing the variation in allometry and wood density of a single species growing in different environmental conditions are rare. Individual trees within a given species have been found to have lower wood density (Nogueira et al., 2007) and shorter height for any given diameter (Nogueira et al., 2008a) in southern Amazonia as compared to central Amazonia. To our knowledge, the present study is the first to develop species-specific allometric equations for populations of a species with parameters specific to each of these subregions. At the community level and at different spatial scales, several studies have shown significant correlations between wood density and environmental variables that are affected by variation in altitude, latitude and soils (Wiemann and Williamson, 2002; Muller-Landau, 2004; Baker et al., 2004; Wittmann et al., 2006; Nogueira et al., 2007; Swenson and Enquist, 2007; Slik et al., 2010).

The present study aimed to compare the architectural features and wood densities of Goupia glabra growing at two different sites in terra-firme (not seasonally flooded) lowland forest in Brazilian Amazonia, which differ mainly in terms of soil type and light condition. Our central hypothesis was that G. glabra would have distinct allometric relationships related to environmental site conditions, and that this may be reflected in its wood density.

\section{Methods}

\subsection{Research sites}

This study was carried out in two areas of commercial timber exploitation in the Brazilian Amazon - one located in the municipality of Apuí, called Fazenda Nova Era (59 $\left.56^{\prime} \mathrm{W} ; 7^{\circ} 18^{\prime} \mathrm{S}\right)$, and the other located in the municipality of Nova Olinda do Norte (hereafter termed NOLinda), called Fazenda Apapazinho (58 $22^{\prime} \mathrm{W}$; $\left.3^{\circ} 48^{\prime} \mathrm{S}\right)$. Both study sites are in the state of Amazonas and are about $400 \mathrm{~km}$ apart along a north-south gradient (Figure 1). Apuí is located near the southern edge of the Amazon forest in the "arc of deforestation," while NOlinda is located in central Amazonia near the Amazon River.

At both sites the average annual temperature is about $27^{\circ} \mathrm{C}$ and the mean maximum and mean minimum are $31^{\circ} \mathrm{C}$ and $23^{\circ} \mathrm{C}$, respectively, while annual precipitation ranges from 2200 to $2300 \mathrm{~mm}$ with two distinct seasons (INMET, 2009, for a 30-year historical series). Precipitation is concentrated between December and April, when the mean monthly rainfall is over $200 \mathrm{~mm}$. However, NOlinda is more uniformly wet, whereas Apuí has a more pronounced decline in precipitation between June and August. Moreover, the sites differ in terms of vegetation, soils and geological formation. The predominant vegetation type in Apuí is open montane wet forest and the soils are mainly Acrisols (red-yellow latosol in the Brazilian system; Santos et al., 2011). In Nova Olinda do Norte, the dominant vegetation is classified as evergreen lowland tropical moist forest and the predominant soils are Xanthic Ferralsols (allic yellow latosol in the Brazilian system), which are heavily weathered, acidic, and very poor in nutrients such as $\mathrm{P}, \mathrm{Ca}$, and $\mathrm{K}$.

\subsection{The studied species}

The genus Goupia is monotypic with just Goupia glabra Aubl. (Goupiaceae). G.glabra is a canopy semideciduous species with ascending branches and cylindrical stem. The bark is gray, with chipped lengthwise lenticels. The bark is $1 \mathrm{~cm}$ thick and comes off in large slabs. G. glabra has a continuous pattern of flowering and fruiting, but flowering peaks usually occur at the end of the dry season and fruiting peaks in the early rainy season. The fruit is a globose berry from 3 to $6 \mathrm{~mm}$ in diameter. Seed number ranges from one to five per fruit. Seeds are approximately $1.5 \mathrm{~mm}$ long and $1 \mathrm{~mm}$ wide and are dispersed primarily by birds (Ribeiro et al., 1999; Ferreira and Tonini, 2004).

G. glabra has a wide distribution, occurring from the tropical rainforests of Panama and Colombia to Amazonian terra firme forests. Trees can reach up to $40 \mathrm{~m}$ in height and up to $130 \mathrm{~cm}$ in diameter at breast height (DBH), growing preferentially either on clayey or well-drained sandy soils (Loureiro et al., 1979; Ferreira and Tonini, 2004). This species is closely associated with gaps (Loureiro et al., 


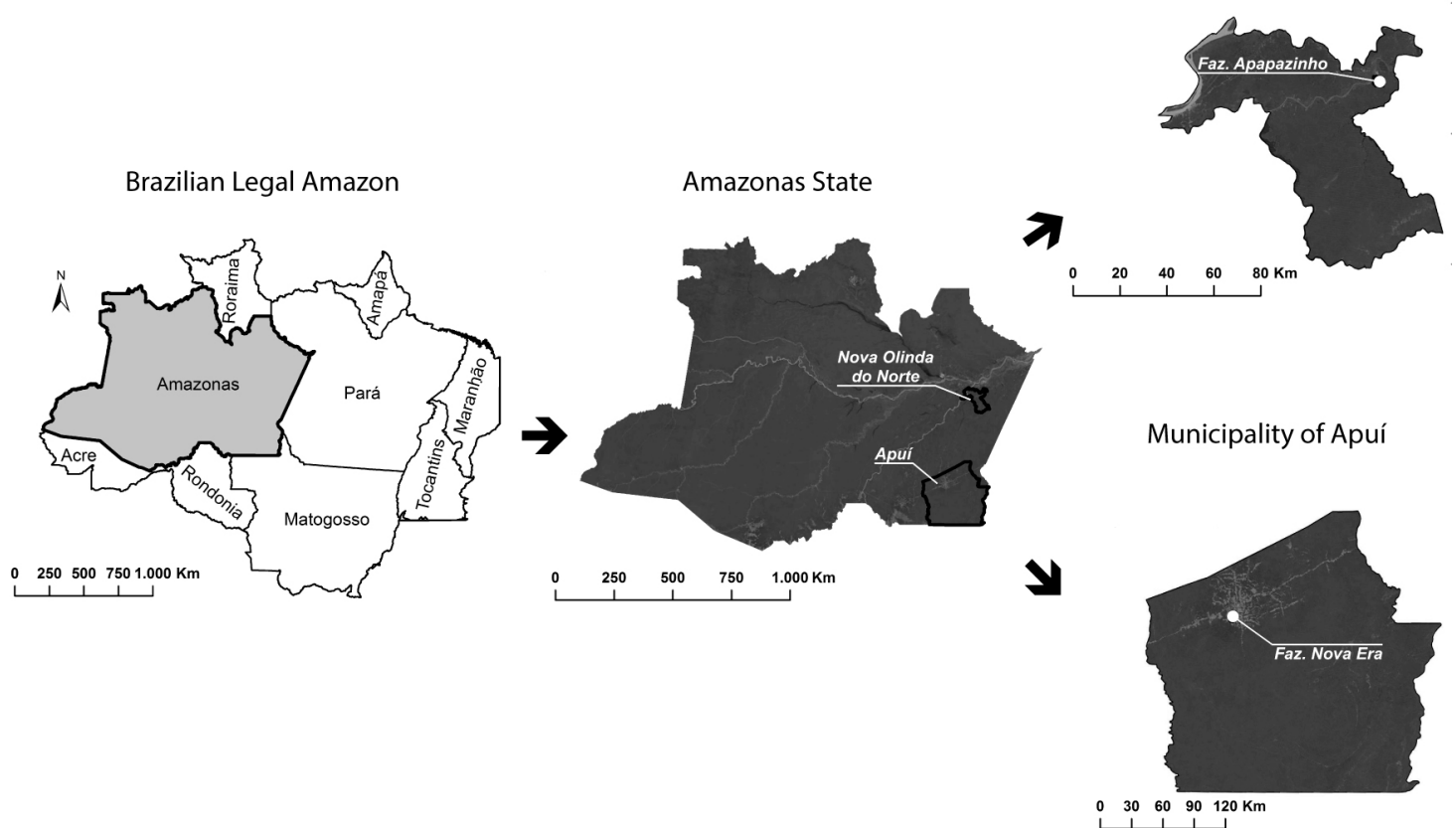

Figure 1. Location of the municipalities of Apuí and Nova Olinda do Norte and of the forest sites where trees were collected and measured in this study.

1979; Boot, 1996) and is classified as a shade-intolerant pioneer species (sensu Swaine and Whitmore, 1988). Although its wood is heavy, with a density ranging from 0.7 to $0.9 \mathrm{~g} / \mathrm{cm}^{3}$, G. glabra has relatively high growth rates in sites with direct sunlight (Loureiro et al., 1979).

\subsection{Data collection}

We measured 29 individuals of G. glabra in Apuí and 36 in NOlinda. Individuals with damage to the canopy and/or trunk were avoided. At both sites, G. glabra trees were collected in logging concessions that encompass 452 ha and 820 ha in Apuí and NOlinda, respectively. We aimed to obtain a uniform distribution of the number of individuals across the DBH size classes at both sites.

For each sampled tree $\geq 10 \mathrm{~cm} \mathrm{DBH}$, the following data were recorded: $\mathrm{DBH}$, stem height $\left(\mathrm{H}_{\mathrm{s}}\right)$, total height $\left(\mathrm{H}_{\mathrm{t}}\right)$, crown length $\left(\mathrm{C}_{\mathrm{h}}\right)$, crown diameter $\left(\mathrm{C}_{\mathrm{d}}\right)$, commercial volume $\left(\mathrm{V}_{\mathrm{c}}\right)$, stem form factor $(\mathrm{FF})$, and wood density $\left(\mathrm{D}_{\mathrm{g}}\right)$. DBH was measured at 1.30 meters above ground level, or just above any buttresses. $\mathrm{H}_{\mathrm{s}}$ is the vertical distance between $\mathrm{t}_{\mathrm{h}}$ e ground level and the height of the lowest living branch. $\mathrm{C}_{\mathrm{h}}$ was defined as the difference between the first branch and final height of the crown, and $\mathrm{H}_{\mathrm{t}}$ is the sum of $\mathrm{H}_{\mathrm{s}}$ and $\mathrm{C}_{\mathrm{h}} \mathrm{C}_{\mathrm{d}}$ was estimated by measuring the horizontal distance from the trunk to the vertical projection of the crown edge in four compass directions $90^{\circ}$ apart. $\mathrm{C}_{\mathrm{d}}$ of a tree was calculated by the arithmetic mean of the two perpendicular directions of the crown. $\mathrm{V}_{\mathrm{c}}$ was calculated by cubic scaling of the bole using the Smalian method for obtaining the areas of cross sections at $0.5 \mathrm{~m}, 1 \mathrm{~m}$,
$1.3 \mathrm{~m}$, and $2 \mathrm{~m}$ and thereafter at 2-m intervals up to the first living branch. All measurements included the bark. FF was calculated as the ratio between the bole volume calculated by the Smalian formula and cylindrical volume with a cross-sectional area equal to the measured DBH.

Cross sections ( 5 -cm thick) were cut with a chainsaw from each selected tree to determine wood density $\left(\mathrm{D}_{\mathrm{g}}\right)$ at six positions: $0.5 \mathrm{~m}, 1 \mathrm{~m}, 1.3 \mathrm{~m}, 2 \mathrm{~m}$, middle and top of the bole. The samples were divided into heartwood, sapwood and bark and were weighed in the field on a portable electronic balance. The volume of each sample was determined immediately after collection to avoid dehydration. The wood samples were fixed on a stylus and submerged in a container of water placed on a balance. According to the Archimedes principle, the volume of water displaced by the immersed sample without touching the container corresponds to the volume of the sample; the amount was recorded in grams, since the density of water is near $1 \mathrm{~g} / \mathrm{cm}^{3}$ (ASTM, 2002). Subsequently, the samples were placed in paper bags and dried in an oven with forced air circulation at $105^{\circ} \mathrm{C}$ (ASTM, 2002). After a week, we began weighing each sample at intervals of 24 hours. The average basic wood density for each tree was calculated as the ratio between the dry weight and the volume of the fresh sample.

\subsection{Data analysis}

Dimensional relationships of G. glabra within each site were determined by least square linear regressions. Both untransformed and logarithmically-transformed 
$\left(\log _{10}\right)$ regressions were performed; the latter substantially improved the fit for some relationships. For each allometric relationship, $95 \%$ confidence intervals around the intercepts and slopes were calculated using the bootstrap technique (Efron and Tibshirani, 1993). For each site, 1000 bootstrap samples were drawn with replacement. Bootstrapping was also used to indicate a $p$-value for statistically significant differences between sites in terms of intercept and slope. To achieve this, 1000 bootstrap sample pairs (each pair encompassing all 65 trees) were drawn in order to obtain the null distribution of no difference between sites (i.e, $\mathrm{H}_{0}$ : Apuí - NOlinda $=0$ ). The probability $p$ for rejection of $\mathrm{H}_{0}$ was obtained by the proportion of cases in which the observed differences of the intercepts and slopes between Apuí and NOlinda were smaller than 0.05. In other words, the observed difference was large enough to state that it was not due to chance alone.

Exponential nonlinear models were tested to determine the relationship between tree size $(\mathrm{DBH})$ and wood density for each site separately. Two-way analysis of variance was used to test the effects on wood density of site and of the position of the cross section along the length of the bole. The effect of position in this analysis was calculated for three positions: $1.30 \mathrm{~m}$ (the $\mathrm{DBH}$ measurement point), $50 \%$ (the midpoint of the bole) and the top of the bole. Because it is not appropriate to assume that samples are independent within the same bole, we randomly selected different trees to obtain the wood density of each bole position within each site.

\section{Results}

\subsection{Allometry}

All linear regressions for $\mathrm{DBH}$ versus the other variables $\left(\mathrm{H}_{\mathrm{s}}, \mathrm{H}_{\mathrm{t}}, \mathrm{C}_{\mathrm{h}}\right.$, and $\left.\mathrm{C}_{\mathrm{d}}\right)$ were significant, except $\log _{10}(\mathrm{DBH})$ versus $\log _{10}\left(C_{h}\right)$ for Apuí (Table 1, Figure 2a). There was no significant difference between sites for DBH versus $\mathrm{H}_{t}$. However, when DBH was regressed against the two variables that compose $\mathrm{H}_{\mathrm{t}}\left(\mathrm{H}_{\mathrm{s}}\right.$ and $\left.\mathrm{C}_{\mathrm{h}}\right)$, both intercepts and slopes were significantly different between sites (Figure 2b, c). Furthermore, Apuí had lower intercept and greater slope for $\log _{10}(\mathrm{DBH})$ versus $\log _{10}\left(\mathrm{H}_{\mathrm{s}}\right)$, and, conversely, greater intercept and lower slope for $\log _{10}(\mathrm{DBH})$ versus $\log _{10}$ $\left(\mathrm{C}_{\mathrm{h}}\right)$. The slope differed significantly between the sites for DBH versus $\mathrm{C}_{\mathrm{d}}$, with greater slope found for NOlinda (Figure 2d). Both slope and the intercept differed between sites for the relationship between $\mathrm{C}_{\mathrm{d}}$ and $\mathrm{H}_{\mathrm{t}}$, with greater intercept and lower slope for Apuí (Figure 2e).

There was a significant difference in stem form factor (FF) between sites $(t=2.66, p=0.01, \mathrm{GL}=63)$. The FF in Apuí $(0.83 \pm 0.082$, mean \pm standard deviation) averaged $7.8 \%$ higher than in NOlinda $(0.77 \pm 0.079)$. Volume fitted as a function of DBH was highly significant for both sites (Apuí: $r^{2}=99.7 \%$; NOlinda: $r^{2}=96.5 \%, p<0.0001$ for both cases, Table 1), and the model parameters differed significantly, with both greater slope and intercept for Apuí (Table 1, Figure 2f).

\subsection{Wood density}

There was a significant positive relationship between DBH and wood density $\left(F_{1,64}=10.48, p=0.001\right)$ for Apuí, for which DBH explained $35.8 \%$ of the variation in wood density. On the other hand, no significant relationship was found for NOlinda $\left(F_{1},{ }_{64}=0.63, p=0.403\right.$, Figure 3$)$. ANOVA detected a highly significant site effect on wood density $\left(F_{1,64}=38.88, p<0.001\right)$. Wood density in NOlinda $(0.74 \pm 0.033$, mean \pm standard deviation $)$ was, on average, $8.8 \%$ higher than in Apuí $(0.68 \pm 0.042)$. The position of the sample in the bole also influenced wood density $\left(F_{2,64}=4.82, p=0.012\right)$, with the wood density at $1.30 \mathrm{~m}$ differed significantly from that at the top of the bole ( $p=0.009$, Tukey test). Wood density decreased from

Table 1. Regression coefficients, bootstrapped $95 \%$ confidence intervals (LL = lower limit and UL= upper limit) and probabilities $(p)$ associated with the rejection of the null hypothesis of no difference between coefficients related to forest sites calculated by bootstrapping. Probabilities in bold denote significant differences between sites at $p<0.05$.

\begin{tabular}{|c|c|c|c|c|c|c|c|c|c|c|}
\hline \multirow{3}{*}{$\begin{array}{l}\text { Allometric } \\
\text { relationships }\end{array}$} & \multirow{3}{*}{$\begin{array}{c}\text { Forest } \\
\text { site }\end{array}$} & \multirow{2}{*}{\multicolumn{2}{|c|}{ Coefficients }} & \multirow{3}{*}{$r^{2}$} & \multicolumn{4}{|c|}{$\begin{array}{c}\text { Bootstrapped } 95 \% \text { confidence } \\
\text { intervals }\end{array}$} & \multirow{2}{*}{\multicolumn{2}{|c|}{$p$}} \\
\hline & & & & & \multicolumn{2}{|c|}{ Intercept } & \multicolumn{2}{|c|}{ Slope } & & \\
\hline & & Intercept & Slope & & $\mathbf{L L}$ & UL & $\mathbf{L L}$ & $\mathbf{U L}$ & Intercept & Slope \\
\hline \multirow{2}{*}{$\mathrm{DBH} v s . \mathrm{H}_{\mathrm{t}}$} & Apuí & 16.22 & 0.20 & 0.44 & 12.04 & 21.02 & 0.09 & 0.31 & \multirow{2}{*}{0.53} & \multirow{2}{*}{0.71} \\
\hline & NOlinda & 17.44 & 0.22 & 0.67 & 15.04 & 20.16 & 0.17 & 0.27 & & \\
\hline \multirow{2}{*}{$\log \mathrm{DBH} v s \cdot \log \mathrm{H}_{\mathrm{s}}$} & Apuí & 0.19 & 0.54 & 0.57 & -0.08 & 0.49 & 0.36 & 0.69 & \multirow{2}{*}{0.002} & \multirow{2}{*}{0.002} \\
\hline & NOlinda & 0.61 & 0.29 & 0.28 & 0.44 & 0.78 & 0.19 & 0.39 & & \\
\hline \multirow{2}{*}{$\log \mathrm{DBH} v s \cdot \log \mathrm{C}_{\mathrm{h}}$} & Apuí & 0.87 & 0.14 & 0.02 & 0.47 & 1.34 & -0.17 & 0.42 & \multirow{2}{*}{0.051} & \multirow{2}{*}{0.03} \\
\hline & NOlinda & 0.52 & 0.39 & 0.46 & 0.37 & 0.75 & 0.26 & 0.49 & & \\
\hline \multirow{2}{*}{ DBH vs. $\mathrm{C}_{\mathrm{d}}$} & Apuí & 3.87 & 0.19 & 0.80 & 2.3 & 5.8 & 0.15 & 0.22 & \multirow{2}{*}{0.47} & \multirow{2}{*}{0.007} \\
\hline & NOlinda & 3.2 & 0.25 & 0.89 & 0.32 & 4.32 & 0.22 & 0.3 & & \\
\hline \multirow{2}{*}{$\mathrm{H}_{\mathrm{t}} v s . \mathrm{C}_{\mathrm{d}}$} & Apuí & 1.42 & 0.45 & 0.39 & -3.58 & 7.52 & 0.24 & 0.64 & \multirow{2}{*}{0.024} & \multirow{2}{*}{0.015} \\
\hline & NOlinda & -5.73 & 0.74 & 0.55 & -16.12 & -0.44 & 0.56 & 1.1 & & \\
\hline \multirow{2}{*}{$\log \mathrm{DBH} v s . \log \mathrm{V}$} & Apuí & -3.94 & 2.49 & 0.98 & -4.16 & -3.68 & 2.33 & 2.62 & \multirow{2}{*}{0.003} & \multirow{2}{*}{0.003} \\
\hline & NOlinda & -3.59 & 2.27 & 0.97 & -3.78 & -3.42 & 2.16 & 2.37 & & \\
\hline
\end{tabular}



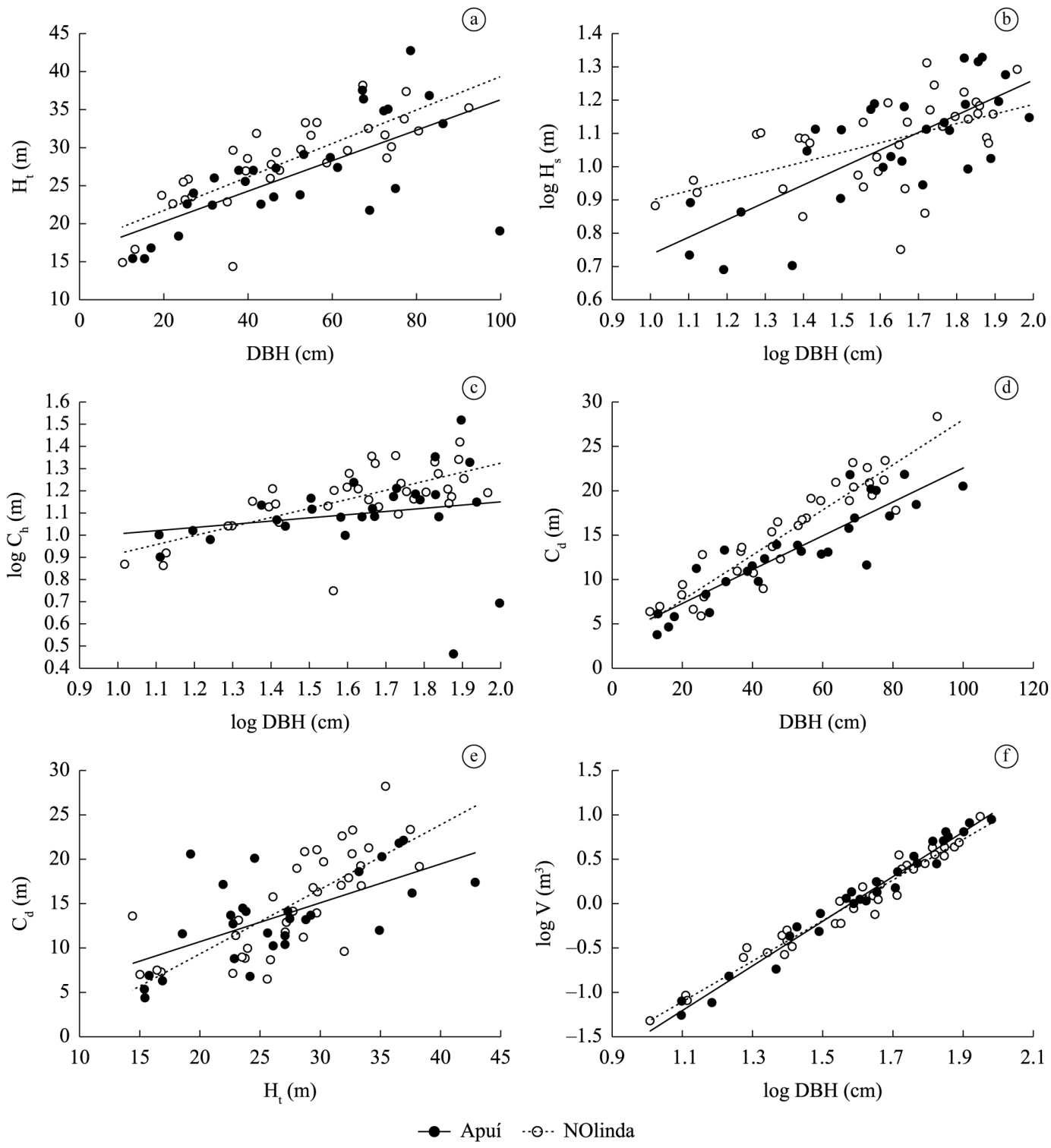

Figure 2. Regression models fitted to data on DBH versus (a) $H_{t}$, (b) $H_{s}$, (c) $C_{h}$ and (d) $C_{d}$, (e) $H_{t}$ versus $C_{d}$ and (f) DBH versus $\mathrm{V}_{\mathrm{c}}$. Regressions of $\mathrm{DBH}$ with $\mathrm{H}_{\mathrm{s}}$ and $\mathrm{C}_{\mathrm{h}}$ are $\log _{10}$-transformed for both axes. Regression coefficients are shown in Table 1.

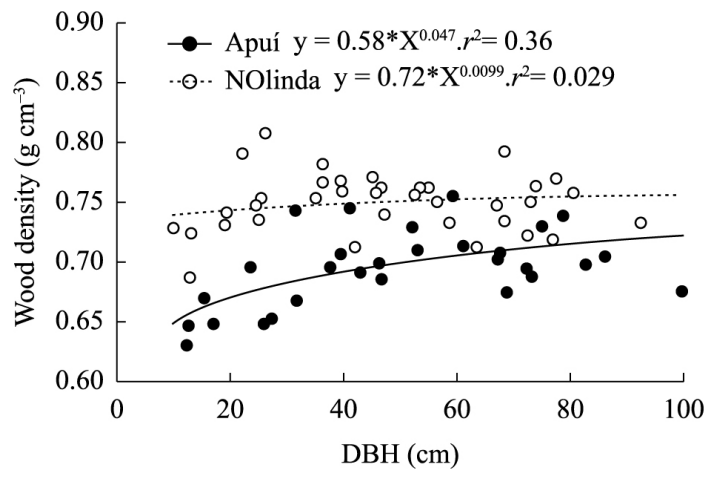

Figure 3. Relationship between DBH and wood density for trees at each forest site. the base to the top of the bole, with the pooled average for both sites being $0.74,0.71$ and $0.70 \mathrm{~g} \mathrm{~cm}^{-3}$ at $1.30 \mathrm{~m}$, middle and at the top of the bole, respectively (Figure 4).

\section{Discussion}

Our findings suggest that the allometry of G. glabra significantly differed between sites, especially regarding to the relationships of crown shape to DBH and height. These differences mirror the interspecific allometric variations within the same site in terms of adult stature (canopy/emerging species versus understory species) and/or demand for light (pioneer versus shade tolerant species) (e.g., King, 1996; Sterck and Bongers, 1998; 


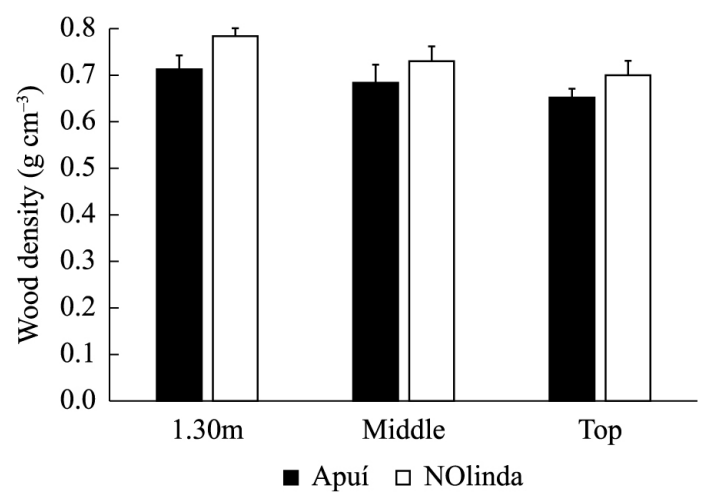

Figure 4. Mean ( \pm standard deviation) of wood density at different stem positions for each forest site.

Poorter et al., 2006). Thus, the allometric differences found in this study can be attributed to abiotic differences related mainly to the quantity and quality of light reaching the understory, as well as the variation in soil physical and chemical characteristics between sites.

Tree architecture within the same species may vary during ontogeny and depends on abiotic conditions (mainly light availability) in which individual trees grow. Rapid changes in the development of the crown may occur when a tree reaches the canopy due to an increase in light exposure (King and Maindonald, 1999; Sterck and Bongers, 2001; Osunkoya et al., 2007). Although G. glabra trees had similar $\mathrm{H}_{t}$ at both sites, this was not true for the relationship between $\mathrm{DBH}$ and $\mathrm{H}_{\mathrm{s}}$, indicating that trees in NOlinda invest more in stem elongation in the smaller size classes, but for larger trees the opposite pattern occurs: trees in Apuí invest more in stem elongation throughout tree ontogeny, which resulted in significantly higher regression slope and lower intercept at this site. Such high initial stem growth in NOlinda can be attributed to the fact that a tree growing in dense rain forest, where it is assumed that light incidence is lower when compared to the open forest in Apuí, needs to invest more in vertical growth at this stage to increase access to light.

The differences in growth in $\mathrm{C}_{\mathrm{d}}$ and $\mathrm{C}_{\mathrm{h}}$ corroborate the reduced growth found for $\mathrm{H}_{\mathrm{s}}$ (in the initial phase) for trees in NOlinda, where they invest less in $\mathrm{C}_{\mathrm{h}}$ and $\mathrm{C}_{\mathrm{d}}$, but have deeper and wider crowns when fully developed. In Apuí the relationship between $\mathrm{DBH}$ and $\mathrm{C}_{\mathrm{h}}$ was not significant, indicating that $\mathrm{C}_{\mathrm{h}}$ remains constant after stems reach a certain height, at least for trees $\geq 10 \mathrm{~cm} \mathrm{DBH}$. Because low light intensity implies a lower photosynthetic rate, perhaps it is a better strategy for a species growing in the dense rainforest to invest energy in early height growth to reach the canopy rapidly and, in later stages, to increase specific leaf area by expanding the canopy to intercept a larger quantity of light. In fact, the variation in bole volume between sites is a consequence of differences in taper (form factor) and $\mathrm{H}_{\mathrm{s}}$ during ontogeny.

Increasing canopy height may result in higher self-shading of the leaves due to the packing of leaf layers (Sterck and
Bongers, 2001). However, the opposite phyllotaxis and the small leaves of $G$. glabra can minimize the effect of canopy shading. In this case, the increase in canopy height could result in an increase in the number of layers of leaves and, by inference, the specific leaf area. Rather, the better light conditions experienced by trees in Apuí means that they do not need to invest large amounts of resources in increasing photosynthetic area. A deep and wide canopy does not necessarily imply a greater number of leaf layers, but the distribution and geometry (shape, size and orientation) of foliage can play a crucial role in the light interception (Poorter et al., 2006).

Allometric differences in this study corroborate the variation in wood density between sites. Wood density is directly related to mechanical structure, and by inference, the ability of a tree to support its own weight and to resist exogenous forces, such as wind and pushing over by other trees (King, 1981; Putz et al., 1983; Chave et al., 2009). However, recent studies have cast doubt on these ideas, showing that the same strength for supporting tree weight is achieved by a trunk with low wood density (with lower construction cost) than by one with higher wood density (Anten and Schieving, 2010). Larjavaara and Muller-Landau (2010) proposed that species with low wood density, such as pioneers, prioritize short-term gains over long-term costs, thereby not only evolving low wood density, but also low trunk and xylem resistance. Low light levels may induce tropical trees to reduce their diameter growth, thus resulting in higher wood density (Thomas, 1996). This also results in a greater investment in vertical growth and crown expansion at the expenses of stem thickness (Sterck et al., 2001; Osunkoya et al., 2007; Poorter et al., 2006). A thinner trunk with high wood density is more flexible than a thicker one with low wood density and equal strength, and flexibility can be advantageous in reducing sail area during short gusts of wind and in allowing the tree to bounce back after having been struck by falling trees or branches. In this sense, the greater crown expansion of G. glabra in NOlinda required more investment in strength and flexibility, and thus in higher wood density. In a rainforest in Borneo, Osunkoya et al. (2007) showed that the safety factor (a measure related directly to physical properties of the wood) had strong positive relationships with crown diameter and depth, indicating that trees (regardless of species) with greater horizontal or vertical crown expansion had higher safety margins against rupture (see also King, 1996; Sterck and Bongers, 1998; Alves and Santos, 2002).

The difference in taper between sites may also represent an adaptive strategy in terms of mechanical support because the increase in the stem base may improve support and fixation (Sposito and Santos, 2001). A larger taper in NOlinda can be related to decreasing risk of deflection of the stem as a result of the greater weight generated by the crown expansion. Therefore, we concluded that there are different adaptive strategies during the ontogeny of G. glabra acting on resource allocation and occupation of space mainly as a result of differences in light availability 
between sites. NOlinda trees need to invest heavily in initial height growth by allocating more carbon per unit volume of stem in this phase, so that an increase in the safety margin against breakage may be achieved when trees reach the canopy and start investing more in crown expansion. In contrast, trees in Apuí allocate less carbon per unit volume of stem during their ontogeny, as canopy expansion is significantly lower than in NOlinda. In fact, the non-significant relationship between $\mathrm{DBH}$ and wood density for NOlinda and the positive relationship for Apuí (Figure 4) demonstrate that carbon allocation to stems in NOlinda occurs equally throughout ontogeny, whereas for trees in Apuí the allocation of biomass changes as the tree grows, with an increase occurring at the end of ontogeny when horizontal crown expansion starts.

Among tropical tree species, tree growth is negatively related to wood density (Thomas, 1996; Muller-Landau, 2004; Nascimento et al., 2005; King et al., 2006). In addition, within the same species wood density is higher in slow-growing trees than in fast-growing trees (Koubaa et al., 2000), indicating that G. glabra may have faster growth in Apuí and, as a result, there must be a difference between sites in the age of trees of same diameter. However, such a difference should be evaluated empirically, and we suggest this approach for future studies.

The distribution of life-history strategies, and particularly the wood density of tropical tree species, may vary among sites depending on environmental features such as climate periodicity, soil conditions, disturbance regimes and competition for light (Muller-Landau, 2004; Nogueira et al., 2007; Patiño et al., 2009). Sites with high disturbance regimes on relatively fertile soils may favor fast-growing species that have low wood density, while sites with lower frequencies of disturbance and with nutrient-poor soils reduce tree growth (Baker et al., 2004; Muller-Landau, 2004). Patiño et al. (2009) have shown that branch xylem density varies considerably across Amazonia, and that $33 \%$ and $26 \%$ of this variation is attributable to phylogeny and environmental factors, respectively. The remaining $41 \%$ is attributable to intraspecific differences related to phenotypic plasticity in many tree species.

In the present study, the difference in wood density between sites is a straightforward consequence of the phenotypic plasticity of G. glabra in response to different environmental conditions. In seasonally flooded várzea (white water floodplain) forests in the Amazon, Wittmann et al. (2006) attributed the differences in wood density of two tree species, Tabebuia barbata and Hevea spruceana, to the level and duration of flooding, which leads to different water conditions and, consequently, to the reduction of tree growth during the aquatic phase, i.e., sites with higher levels and durations of flooding result in greater physiological stress that decreases tree growth and increases wood density. In the present study, differences in soil fertility and disturbance regimes between Apuí and NOlinda can also be considered as crucial factors for different strategies of $G$. glabra growth, and the subject is appropriate for future studies.

\section{Conclusions}

At the community level, allometric differences have been found in trees in different forest types in Amazonia and in other tropical forests (Nogueira et al., 2008a; Feldpausch et al., 2011; Banin et al., 2012). The results of the present study are unique because they show differences in allometric relations and in wood density for the same species growing in two forest types in Brazilian Amazonia. These allometric differences have implications for biomass estimates for this species and represent a warning of one more possible bias in biomass estimates generally when obtained by means of allometric equations. This even applies to those equations that include both tree height and wood density as explanatory variables but assume no differences in crown biomass. In the present study, the biomass of Goupia glabra will be higher at the NOlinda site (central Amazonia) than at the Apuí site (southern Amazonia) due both to denser wood in all trees (Figure 3) and to larger crowns in the case of the trees with large diameters and heights (Figure 3d, e). These height and density differences between central and southern Amazonia are consistent with the pattern for species studied by Nogueira et al. (2007, 2008a, b).

\section{Acknowledgements}

This contribution is part of the first author's Master thesis undertaken at the National Institute of Amazonian Research (INPA), with fellowships from the Amazonas Research Foundation (FAPEAM, process \#143643/2008-8). We are grateful to the landowners, Antonio M. R. de Arrunda, Raimundo de S. Maia Filho, Sergio S. Souza (Fazenda Apapazinho) and Marcos V. Conceicao (Fazenda Nova Era) who provided us financial and logistic support for fieldwork. Our special thanks to Antonio Siliprandi, Norian C. Siliprandi, Nivaldo Carline, Ivone C. Siliprandi Michele Gusmao, Susy D. Souza, Manoel J.F. Mar, Pedro S. Silva and Joaquim G. Silva for assistance in the field.

\section{References}

ALVES, L.F. and SANTOS, F.A.M., 2002. Tree allometry and crown shape of four tree species in Atlantic rain forest, southeast Brazil. Journal of Tropical Ecology, vol. 18, no. 2, pp. 245-260. http://dx.doi.org/10.1017/S026646740200216X.

AMERICAN SOCIETY FOR TESTING AND MATERIALS - ASTM, 2002. Standard test methods for specific gravity of wood and wood-based materials. Designation: D 2395-02. Pennsylvania: ASTM. 75 p.

ANTEN, N.P. and SCHIEVING, F., 2010. The role of wood mass density and mechanical constraints in the economy of tree architecture. American Naturalist, vol. 175, no. 2, pp. 250-260. http://dx.doi.org/10.1086/649581. PMid:20028240.

BAKER, T.R., PHILLIPS, O.L., MALHI, Y., ALMEIDA, S., ARROYO, L., DI FIORE, A., ERWIN, T., KILLEEN, T.J., LAURANCE, S.G., LAURANCE, W.F., LEWIS, S.L., LLOYD, J., MONTEAGUDO, A., NEILL, D.A., PATIÑO, S., PITMAN, N.C.A., SILVA, J.N.M. and MARTÍNEZ, J.V., 2004. Variation 
in wood density determines spatial patterns in Amazonian forest biomass. Global Change Biology, vol. 10, no. 5, pp. 545-562. http://dx.doi.org/10.1111/j.1365-2486.2004.00751.x.

BANIN, L., FELDPAUSCH, T.R., PHILLIPS, O.L., BAKER, T.R., LLOYD, J., AFFUM-BAFFOE, K., ARETS, E.J.M.M., BERRY, N.J., BRADFORD, M., BRIENEN, R.J.W., DAVIES, S., DRESCHER, M., HIGUCHI, N., HILBERT, D.W., HLADIK, A., IIDA, Y., SALIM, K.A., KASSIM, A.R., KING, D.A., LOPEZGONZALEZ, G., METCALFE, D., NILUS, R., PEH, K.S.-H., REITSMA, J.M., SONKÉ, B., TAEDOUMG, H., TAN, S., WHITE, L., WÖLL, H. and LEWIS, S.L., 2012. What controls tropical forest architecture? Testing environmental, structural and floristic drivers. Global Ecology and Biogeography, vol. 21, no. 12, pp. 1179-1190. http://dx.doi.org/10.1111/j.1466-8238.2012.00778.x.

BOOT, R.G.A., 1996. The significance of seedling size and growth rate of tropical forest tree seedlings for regeneration in canopy openings. In: M.D. SWAINE, ed. The ecology of tropical forest tree seedlings. Paris: UNESCO. pp. 267-284. MAS UNESCO Series, Vol. 17

CHAVE, J., COOMES, D., JANSEN, S., LEWIS, S., SWENSON, N.G. and ZANNE, A.E., 2009. Towards a worldwide wood economics spectrum. Ecology Letters, vol. 12, no. 4, pp. 351-366. http:// dx.doi.org/10.1111/j.1461-0248.2009.01285.x. PMid:19243406.

CHAZDON, R.L. and FETCHER, N., 1984. Photosynthetic light environments in a lowland tropical rainforest in Costa Rica. Journal of Ecology, vol. 72, no. 3, pp. 552-564.

EFRON, B. and TIBSHIRANI, R.J., 1993. An introduction to the bootstrap. New York: Chapman \& Hall. 456 p.

FELDPAUSCH, T.R., BANIN, L., PJILLIPS, O.L., BAKER, T.R., LEWIS, S.L., QUESADA, C.A., AFFUM-BAFFOE, K., ARETS, E.J.M.M., BERRY, N.J., BIRD, M., BRONDIZIO, E.S., CAMARGO, P., CHAVE, J., DIAGBLETEY, G., DOMINGUES, T.F., DRESCHER, M., FEARNSIDE, P.M., FRANÇA, M.B., FYLLAS, N.M., LOPEZ-GONZALEZ, G., HLADIK, A., HIGUSHI, N., HUNTER, M.O., IIDA, Y., SALIM, K.A., KASSIM, A.R., KELLER, M., KEMP, J., KING, D.A., LOVETT, J.C., MARIMON, B.S., MARIMON-JUNIOR, B.H., LENZA, E., MARSHALL, A.R., METCALFE, D.J., MITCHARD, E.T.A., MORAN, E.F., NELSON, B.W., NILUS, R., NOGUEIRA, E.M., PALACE, M., PATIÑO, S., PEH, K.S.-H., RAVENTOS, M.T., REITSMA, J.M., SAIZ, G., SCHRODT, F., SONKÉ, B., TAEDOUMG, H.E., TAN, S., WHITE, L., WÖLL, H. and LLOYD, J., 2011. Heightdiameter allometry of tropical forest trees. Biogeosciences, vol. 8, no. 5, pp. 1081-1106. http://dx.doi.org/10.5194/bg-8-1081-2011

FERREIRA, L.M.M. and TONINI, H., 2004. Cupiúba (Goupia glabra Aublet): crescimento, potencialidades e usos. Boa Vista: Embrapa Roraima. 27 p. Documentos, no. 4.

INSTITUTO NACIONAL DE METEOROLOGIA - INMET, 2009 [viewed 5 June 2013]. Normais Climatológicas do Brasil 1961-1990. Brasília. IMET [online]. Available from: http://www. inmet.gov.br/portal/index.php?r=clima/normaisclimatologicas

KING, D.A. and MAINDONALD, J.H., 1999. Tree architecture in relations to leaf dimensions and tree stature in temperate and tropical rain forests. Journal of Ecology, vol. 87, no. 6, pp. 1012-1024. http://dx.doi.org/10.1046/j.1365-2745.1999.00417.x.

KING, D.A., 1981. Tree dimensions: maximizing the rate of height growth in dense stands. Oecologia, vol. 51, no. 2, pp. 351-356. http://dx.doi.org/10.1007/BF00540905.
KING, D.A., 1996. The allometry and life history of tropical trees. Journal of Tropical Ecology, vol. 12, no. 1, pp. 25-44. http://dx.doi.org/10.1017/S0266467400009299.

KING, D.A., DAVIES, S.J., TAN, S. and NOOR, N.S.M., 2006. The role of wood density and stem support costs in the growth and mortality of tropical trees. Journal of Ecology, vol. 94, no. 3, pp. 670-680. http://dx.doi.org/10.1111/j.1365-2745.2006.01112.x.

KOUBAA, A., ZHANG, S.Y., ISABEL, N., BEAULIEU, J. and BOUSQUET, J., 2000. Phenotypic correlations between juvenile mature wood density and growth in black spruce. Wood and Fiber Science, vol. 32, no. 1, pp. 61-71.

LARJAVAARA, M. and MULLER-LANDAU, H.C., 2010. Rethinking the value of high wood density. Functional Ecology, vol. 24, no. 4, pp. 701-705. http://dx.doi.org/10.1111/j.13652435.2010.01698.x.

LOUREIRO, A., SILVA, M.F. and ALENCAR, J.C., 1979. Essências madeireiras da Amazônia. Manaus: SUFRAMA. 432 p.

MULLER-LANDAU, H.C., 2004. Interspecific and inter-site variation in wood specific gravity of tropical trees. Biotropica, vol. 36 , no. 1, pp. 20-32.

NASCIMENTO, H.E.M., LAURANCE, W.F., CONDIT, R., LAURANCE, S.G., D'ANGELO, S. and ANDRADE, A.C., 2005. Demographic and life-history correlates for Amazonian trees. Journal of Vegetation Science, vol. 16, no. 6, pp. 625-634. http://dx.doi.org/10.1111/j.1654-1103.2005.tb02405.x.

NIKLAS, K.J., 1993. Influence of tissue density-specific mechanical properties on the scaling of plant height. Annals of Botany, vol. 72 , no. 3, pp. 173-179.

NOGUEIRA, E.M., FEARNSIDE, P.M., NELSON, B.W. and FRANÇA, M.B., 2007. Wood density in forests of Brazil's arc of deforestation: implications for biomass and flux of carbon from land-use change in Amazonia. Forest Ecology and Management, vol. 248, no. 3, pp. 119-135. http://dx.doi.org/10.1016/j. foreco.2007.04.047.

NOGUEIRA, E.M., NELSON, B.W., FEARNSIDE, P.M., FRANÇA, M.B. and OLIVEIRA, A.C.A., 2008a. Tree height in Brazil's 'arc of deforestation': shorter trees in south and southwest Amazonia imply lower biomass. Forest Ecology and Management, vol. 255, no. 7, pp. 2963-2972. http://dx.doi. org/10.1016/j.foreco.2008.02.002.

OSUNKOYA, O.O., OMAR-ALI, K., AMIT, N., DAYAN, J., DAUD, D.S. and SHENG, T.K., 2007. Comparative heightcrown allometry and mechanical design in 22 tree species of Kuala Belalong rainforest, Brunei, Borneo. American Journal of Botany, vol. 94, no. 12, pp. 1951-1962. http://dx.doi.org/10.3732/ ajb.94.12.1951. PMid:21636390.

PATIÑO, S., LLOYD, J., PAIVA, R., BAKER, T.R., QUESADA, C.A., MERCADO, L.M., SCHMERLER, J., SCHWARZ, M., SANTOS, A.J.B., AGUILAR, A., CZIMCZIK, C.I., GALLO, J., HORNA, V., HOYOS, E.J., JIMENEZ, E.M., PALOMINO, W., PEACOCK, J., PEÑA-CRUZ, A., SARMIENTO, C., SOTA, A., TURRIAGO, J.D., VILLANUEVA, B., VITZTHUM, P., ALVAREZ, E., ARROYO, L., BARALOTO, C., BONAL, D., CHAVE, J., COSTA, A.C.L., HERRERA, R., HIGUCHI, N., KILLEEN, T., LEAL, E., LUIZÃO, F., MEIR, P., MONTEAGUDO, A., NEIL, D., NÚÑEZ-VARGAS, P., PEÑUELA, M.C., PITMAN, N., PRIANTE FILHO, N., PRIETO, A., PANFIL, S.N., RUDAS, A., SALOMÃO, R., SILVA, N., SILVEIRA, M., SOARES DEALMEIDA, S., TORRES-LEZAMA, A., VÁSQUEZ-MARTÍNEZ, R., VIEIRA, I., MALHI, Y. and PHILLIPS, O.L., 2009. Branch xylem density 
variations across the Amazon Basin. Biogeosciences, vol. 6, no. 4, pp. 545-568. http://dx.doi.org/10.5194/bg-6-545-2009.

POORTER, L., BONGERS, L. and BONGERS, F., 2006. Architecture of 54 moist-forest tree species: traits, trade-offs, and functional groups. Ecology, vol. 87, no. 5, pp. 1289-1301. http://dx.doi.org/10.1890/0012-9658(2006)87[1289:AOMTST] 2.0.CO;2. PMid:16761607.

PUTZ, F.E., COLEY, P.D., LU, K., MONTALVO, A. and AIELLO, A., 1983. Uprooting and snapping of trees: structural determinants and ecological consequences. Canadian Journal of Forest Research, vol. 3, no. 5, pp. 1011-1020. http://dx.doi. org/10.1139/x83-133.

RIBEIRO, J.E.L., HOPKINS, M.J.G., VICENTINI, A., SOTHERS, C.A., COSTA, M.A.S., BRITO, J.M., SOUZA, M.A.D., MARTINS, L.H.P., LOHMAN, L.G., ASSUNÇÃO, P.A.C.L., PEREIRA, E.C., SILVA, C.F., MESQUISTA, M.R. and PROCÓPIO, L.C., 1999. Flora da Reserva Ducke: guia de identificação das plantas vasculares de uma floresta de terra-firme na Amazônia Central. Manaus: INPA. 816 p.

SANTOS, H.G., CARVALHO JÚNIOR, W., DART, R.O., ÁGLIO, M.L.D., SOUZA, J.S., PARES, J.G. and FONTANA, A., MARTINS, A.L.S. and OLIVEIRA, A.P., 2011. O novo mapa de solos do Brasil: legenda atualizada. 2nd ed. Rio de Janeiro: Embrapa Solos. 67 p. Documentos, no. 130.

SLIK, J.W.F., AIBA, S.-I., BREARLEY, F.Q., CANNON, C.H., FORSHED, O., KITAYAMA, K., NAGAMASU, H., NILUS, R., PAYNE, J., PAOLI, G., POULSEN, A.D., RAES, N., SHEIL, D., SIDIYASA, K., SUZUKI, E. and VAN VALKENBURG, J.L.C.H., 2010. Environmental correlates of tree biomass, basal area, wood specific gravity and stem density gradients in Borneo's tropical forests. Global Ecology and Biogeography, vol. 19, no. 1, pp. 50-60. http://dx.doi.org/10.1111/j.1466-8238.2009.00489.x.

SPOSITO, T.C. and SANTOS, F.A.M., 2001. Scaling of stem and crown in eight Cecropia (Cecropiaceae) species of Brazil.
American Journal of Botany, vol. 88, no. 5, pp. 939-949. http:// dx.doi.org/10.2307/2657047. PMid:11353719.

STERCK, F.J. and BONGERS, F., 1998. Ontogenetic changes in size, allometry, and mechanical design of tropical rain forest trees. American Journal of Botany, vol. 85, no. 2, pp. 266-272. http://dx.doi.org/10.2307/2446315. PMid:21684910.

STERCK, F.J. and BONGERS, F., 2001. Crown development in tropical rain forest trees: patterns with tree height and light availability. Journal of Ecology, vol. 89, no. 1, pp. 1-13. http:// dx.doi.org/10.1046/j.1365-2745.2001.00525.x.

STERCK, F.J., BONGERS, F. and NEWBERY, D.M., 2001. Tree architecture in a Bornean lowland rainforest: intraspecific and interspecific patterns. Plant Ecology, vol. 153, no. 1, pp. 279-292. http://dx.doi.org/10.1023/A:1017507723365.

SWAINE, M. and WHITMORE, T.C., 1988. On definition of ecological species groups in tropical rain forests. Vegetatio, vol. 75, no. 1, pp. 81-86. http://dx.doi.org/10.1007/BF00044629.

SWENSON, N.G. and ENQUIST, B.J., 2007. Ecological and evolutionary determinants of a key plant functional trait: wood density and its community wide variation across latitude and elevation. American Journal of Botany, vol. 94, no. 3, pp. 451459. http://dx.doi.org/10.3732/ajb.94.3.451. PMid:21636415.

THOMAS, S.C., 1996. Asymptotic height as a predictor of growth and allometric characteristics in Malaysian rain forest trees. American Journal of Botany, vol. 83, no. 5, p. 556-566.

WIEMANN, M.C. and WILLIAMSON, G.B., 2002. Geographic variation in wood specific gravity: effects of latitude, temperature, and precipitation. Wood and Fiber Science, vol. 34, no. 1, pp. 96-107.

WITTMANN, F., SCHÖNGART, J., PAROLIN, P., WORBES, M., PIEDADE, M.T.F. and JUNK, W.J., 2006. Wood specific gravity of trees in Amazonian white-water forests in relation to flooding. IAWA Journal, vol. 27, no. 3, pp. 255-268. 